Revista de la red interuniversitaria de estudios sobre las literaturas rioplatenses contemporáneas en Francia

$18 \mid 2018$

El río y la ciudad

\title{
En el Oeste
}

\section{Marta Inés Waldegaray}

URL: http://journals.openedition.org/lirico/6076

DOI: 10.4000/lirico.6076

ISSN: 2262-8339

Editor

Réseau interuniversitaire d'étude des littératures contemporaines du Río de la Plata

Referencia electrónica

Marta Inés Waldegaray, « En el Oeste », Cuadernos LIRICO [En línea], 18 | 2018, Puesto en línea el 02 diciembre 2018, consultado el 01 mayo 2019. URL : http://journals.openedition.org/lirico/6076 ; DOI : 10.4000/lirico.6076

Este documento fue generado automáticamente el 1 mayo 2019.

\section{(c) $(1) \Theta \Theta$}

Cuadernos LIRICO está distribuido bajo una Licencia Creative Commons Atribución-NoComercialSinDerivar 4.0 Internacional. 


\section{En el Oeste}

\section{Marta Inés Waldegaray}

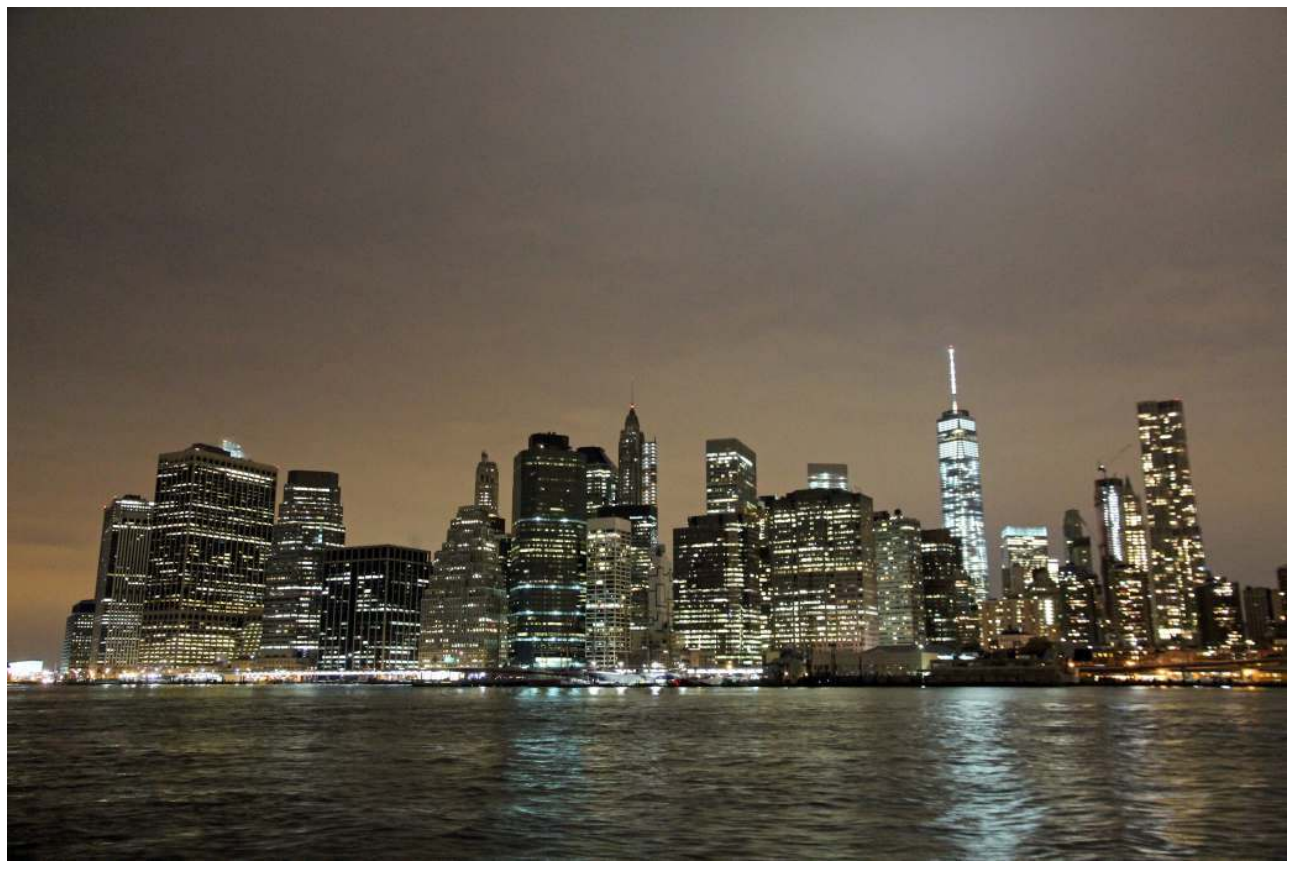

VISTA NOCTURNA DE MANHATTAN-NUEVA YORK DESDE EL RÍO HUDSON. FOTO TOMADA POR MARTA INÉS WALDEgARAY EL 21 DE DICIEMBRE DE 2014.

Nueva York, quai ouest, muelle oeste, comienzo de los años 80: zona de hangares abandonados propicios a los ajustes de cuentas por los cuales circulan mendigos, gitanos, individuos ociosos, inmigrantes, homosexuales. Área desolada en los tiempos neoyorkinos de Koltès (años 70) y rehabilitada a finales de los 80 , después de su muerte (Riverbank State Park, North River Wastewater Treatment Plant).

Topografía neoyorkina: ayudado por su secretaria (Monique), un alto ejecutivo (Maurice Koch... Rolex, Weston, Jaguar) proveniente del este de Manhattan (del Upper East Side, espacio de los wasp), cruza en su lujoso coche la isla hacia el oeste, allí donde la clase media y la actividad comercial ya no existen ("ce n'est pas le monde vivant, ici"), un sector extraño y oscuro carente de servicios públicos y apropiado por las cucarachas, las ratas, 
los negros y los extranjeros que hablan español y quechua. Psíquicamente quebrado y económicamente arruinado ("ma réputation est à l'eau"), Koch se interna en uno de esos hangares desmantelados, situados entre las aguas del Hudson y la Riverside Drive ("mur d'obscurite"), con la firme intención de suicidarse tirándose al río ("Je veux seulement qu'on me laisse approcher du fleuve") con piedras en los bolsillos para asegurarse la muerte. Ambos encontrarán en ese lugar a un grupo de marginales que anhelan las luces de la ciudad ("les lumières du port qui viennent de l'autre côte"). Se trata de una familia de inmigrantes peruanos (Cécile y Rodolphe, con sus dos hijos: Claire y Charles) y de un enigmático personaje negro (Abad) que pronuncia sonidos ininteligibles y se pasea por la orilla del río como guardián de las almas en pena que buscan partir al más allá; un personaje que progresivamente irá adquiriendo una función dramática relevante. Sin embargo Koch, representación del blanco burgués, fracasa en su intento. Como el hombre rico que, en una escena cumbre de Luces de la ciudad (1931), al intentar suicidarse tirándose a un río con una piedra al cuello era rescatado del agua por un vagabundo sin hogar: Charlot, contra todo lo previsto, Koch también es rescatado del Hudson por un marginal: el negro Abad. Se establece a partir de esta escena inaugural un juego de tensiones y contrastes. Mientras que los personajes que viven en ese muelle en penumbras anhelan escapar de allí (e impiden una y otra vez que la pareja abandone el lugar, guiados por la intención de obtener de ambos aquello que les falta para lograr huir), alguien venido de fuera (Koch), del este, desde aquel otro mundo lumínico que simboliza el éxito social, busca ultimar en el oeste el proceso de hundimiento que ya inició.

La oscura y espectral horizontalidad del muelle frente a la luminosa verticalidad de la gran urbe neoyorkina, el oeste y el este de la isla, y a su vez las riberas al este y al oeste del Hudson, espacializan la confrontación social entre territorios próximos y culturalmente diferentes en esta obra de Koltès, casi carente de intriga (o cuya intriga primaria sería la de saber si Koch logrará finalmente arrojarse al río y morir) y en la cual, básicamemente, se trata de dramatizar las relaciones sociales entre personajes que disparatadamente comparten un mismo sustrato ético compuesto de ingratitud e individualismo.

Escrita entre 1983 y 1985 a pedido de la Comédie de l'Est, Quai Ouest (Muelle Oeste) exhibe de manera trágica y grotesca a la vez algunas temáticas propias de lo que se identifica como el fin de las ilusiones de prosperidad de la sociedad capitalista que modelaron la subjetividad moderna; una desilusión que adquiere en el teatro del dramaturgo francés el carácter del desamparo, del aislamiento de los más débiles, del choque de culturas, y también, visionariamente, del vértigo existencial al que están sujetos los inmigrantes clandestinos. Así como Luces de la ciudad dramatizaba la crisis del sistema capitalista posterior a la caída de la bolsa de Nueva York en octubre de 1929, puntapié inicial de la Gran Depresión, aunque planteado desde la generosidad que ilumina las relaciones humanas en el universo de Charlot, medio siglo más tarde, el espiral descendente de la recesión económica en el corazón del mundo capitalista, nuevamente, opera en Quai Ouest como telón de fondo que incita a los mezquinos personajes de Koltès a aller à l'ouest, to go west. Al oeste, espacio de pasaje entre el limbo social y la muerte... un muelle, nebuloso borde existencial... y un río, ilusoria promesa de salvación. 